\title{
The Brand Through the Prism of a Model - An Interdisciplinary Concept
}

\author{
Jana Burešová ${ }^{1}$ \\ ${ }^{1}$ Faculty of Economics and Management, Czech University of Life Sciences in Prague, Czech Republic \\ Correspondence: Jana Burešová, Faculty of Economics and Management, Department of Management, Czech \\ University of Life Sciences in Prague, Kamýcká 961/129, 16521 Praha 6 - Suchdol, Czech Republic. E-mail: \\ buresovaj@seznam.cz
}

Received: March 17, 2015

Accepted: March 30, 2015

Online Published: May 17, 2016

doi:10.5539/mas.v10n7p188

URL: http://dx.doi.org/10.5539/mas.v10n7p188

\begin{abstract}
A brand is a symbol that is created by the strategic management of the brand, so-called brand management, which is a dynamically developing discipline in the field of international marketing. If the brand is legally protected, it is called a registered trademark. In this form, it fulfils the essence of intellectual property in the sense of the law and plays a vital and strategic role in the assets of the company. It helps create business opportunities, and, generally speaking, it strives to make the maximum of its value. To fully comprehend it, it is necessary to understand the interdisciplinary circumstances that helped create the brand and its unique identification. The aim of this paper is to present a model that offers an interdisciplinary perspective on a brand with the potential to expand its unique identification.
\end{abstract}

Keywords: brand, brand platform, identity, image, positioning, strategic brand management, trademark

\section{Introduction}

A brand is a pheomenon that generally represents the graphic rendering of a logo, accompanied by a trade name identified with specific products and services. If the brand is legally protected, it is called a trademark. In this form, the brand fulfils the essence of property in terms of the meaning of the law. When it has already become recognizable and has its own name, an important position on the market, and its own identity, it can be considered a brand. Therefore, how a brand operates defines it as such. According to Keller (2013), we can see the differences between a brand with a small "b" and a Brand with a big "B."

During its long existence, a brand has been accompanied by strategic brand management, which, like all other forms of management, is an effort to control the subject of interest, in this case the brand. We can say that brand management tries to create an emotional attachment between the company, the product, and the consumer through the brand, which needs to be differentiated. A product offered by a company thus becomes an instrument that enables customers to experience the stories the brand is telling.

What has been developing in Europe is leading to the unification of the legal basis of the brand as a trademark (the current reform), and there is much more pressure on targeted brand management and its appropriate demonstration of certain attributes. The need to understand the individual interconnected interdisciplinary relationships that blend into one another, are dependent upon one another, and help create a stronger brand becomes more relevant.

This study has an interdisciplinary character and presents a way to judge a brand using a model that leads to the creation of a brand with a unique identification, i.e. a uniquely perceived brand.

\section{Methods}

The aim of the study is to present a theoretical model of a brand and its individual components, layers, and mutual relationships leading to its expansion and creating its unique identification. 


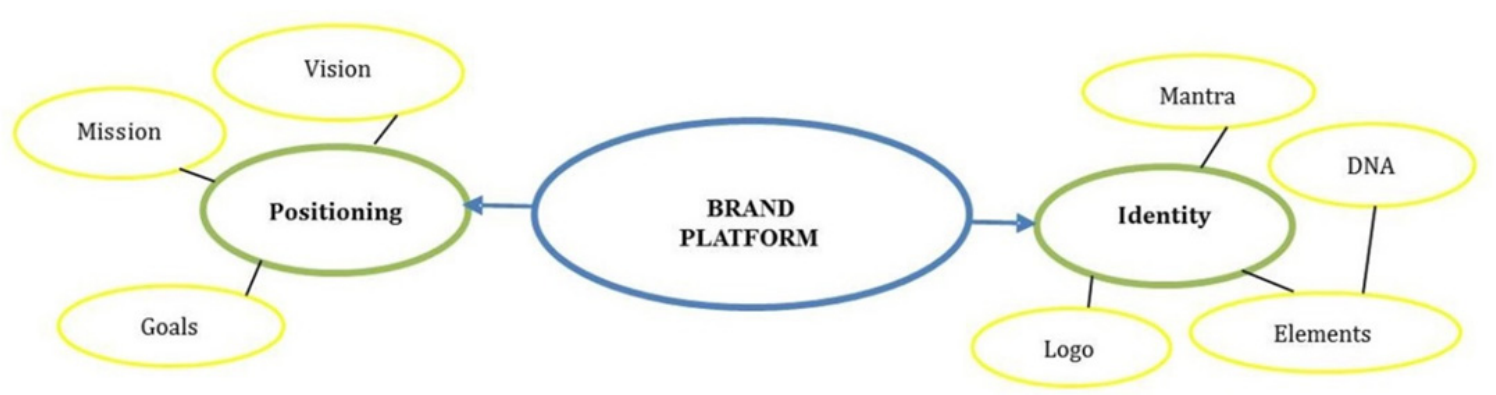

Figure 1. The elements from the point of view of the owner of the brand

The theoretical model is the result of induction, i.e. a generalization of real situations. It was developed based on an analysis of documents, comparisons, follow-up deductions, and identification of the areas that have an impact on the creation of the brand. Within the model, identified areas, i.e. elements from the point of view of the brand's owner, at the level of its platform (Fig. 1) as well as perception (acceptance) and experience with the brand (Fig. 2) were synthetically integrated. Other areas leading to the identification of the most important factors that help create the brand with a unique identification and their individual mutually influential relationships were integrated into the model based on practical experience.

The resulting model, offering an interdisciplinary perspective on the brand, was constructed out of theoretical conclusions and empirically gained facts.

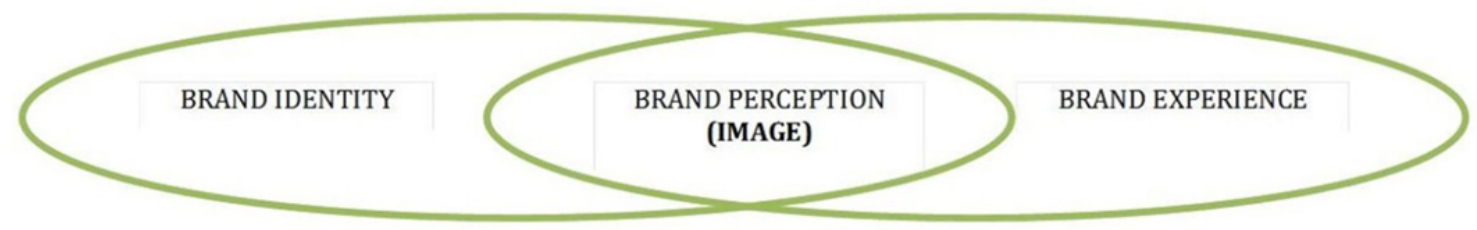

Figure 2. The elements from the point of view of the customer

\section{Results}

The final model cyclically interconnects the individual interdisciplinary approaches to brands with expansive potential into a compact whole with the above-mentioned interdisciplinary links and relationships.

\subsection{Basic Pillars}

Marketing, legal, and value perspectives on the brand can be seen as pillars (Fig. 3) upon which a brand can be created and built. The marketing, legal, and value pillar and its separate levels and parts mutually interact and influence one another. The marketing pillar is concerned with the brand's communication towards customers; the legal pillar deals with the question of the ownership, intellectual property, protecting and defending the brand; and the value pillar deals with the value of the brand and its ability to attract the attention, i.e. financial and emotional value.

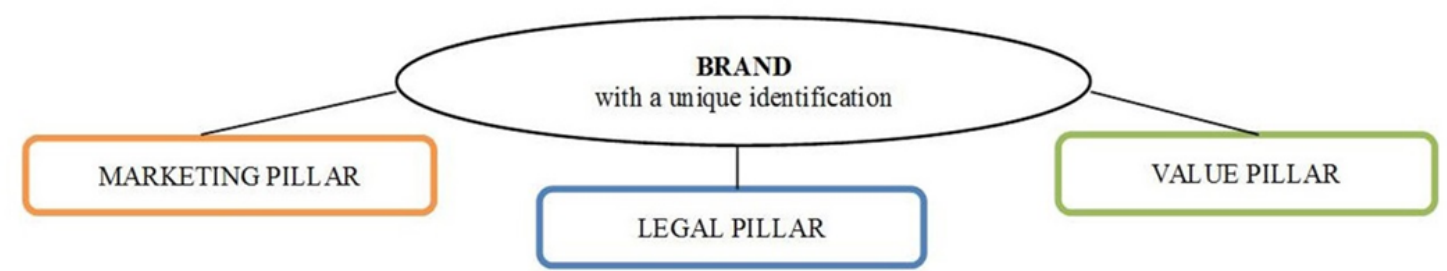

Figure 3. Basic pillars 


\subsection{The Basic Level}

An entity (company) that offers a product (products and services) under its commercial name, creates its own individual company identity, and tries to find its place on the market is at the basic level. These are mainly non-brand name products, agricultural commodities (potatoes...) etc. Some of the elements, such as its name, products, and others are integral parts of its intellectual property; for example, the company is registered (for legal entities the business register, Trustee or Foundation, or for natural individuals the trade licence).

\subsection{The Brand Level}

The brand level is the level of status and is defined by the platform of the brand, specifying the brand's essence and spirit, and it is possible to divide it, depending on the approach, into the identity of the brand that states what the brand is, gives the brand its direction, and should be consistent; the positioning of the brand that determines its main competitive advantage is based on it, and it should conform to the relevant market (Fig. 4). The individual elements of the label do not act in isolation and there is a synergetic effect among them.

By connecting the name (subject) and graphic image (logo), which is composed of the individual specific elements underlining the character of the label and its meaning and/or an idea, a label (brand) can be created that is subject to copyright and is the basis of the brand level from the point of view of the owner of the label (company), who creates the label in its own image.

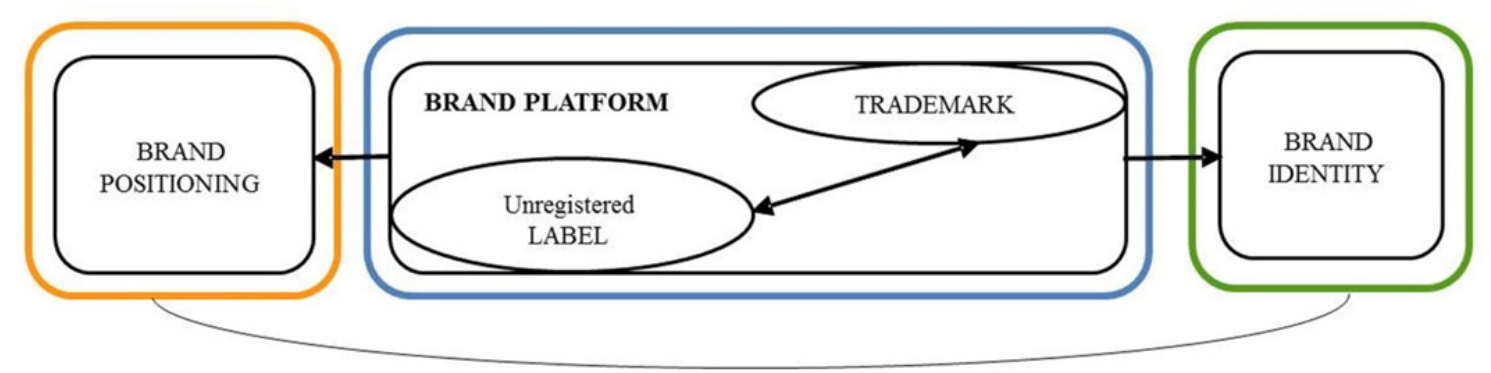

Figure 4. The Brand level

In the legal pillar, the platform of the brand has a legal framework, and in it there is an unregistered label (trade name), which is only protected during an unfair competition, or a trademark through which the individual elements of the label in relation to the products or services offered by the brand are legally protected, which means that the name of the subject in combination with the trademark strengthens its position on the market. Within the legal pillar, for the trademark to obtain legal protection it is necessary to apply for a registration at the relevant administrative office and thusly begin administrative proceedings. If the registration is successful, it is necessary to activate the trademark (e.g. to use it, make it part of common awareness etc.), because this right could expire and the trademark could easily revert to an unregistered label.

In the marketing pillar, the brand's strategic base is its uniqueness (differentiation), on which the idea of the brand, i.e. its own significance, is built. The vision of the brand, expressing its purpose, basic vision of the future, and its aim, which generally remains the same, is established based on the idea of the brand. The brand should represent the productivity and the mission of the subject (company) and further transfer its value and message through the mantra of the brand. Concrete strategic goals emerge from the formulated mission, i.e. the final required status on which the strategies are based. These would not possible without an assessment of the position of the brand on the market in the minds of the targeted customers. The positioning of the brand is at the center of these marketing strategies, because their management fixates the brand in the minds of customer and its feedback is the evaluation of its image and perception. The positioning is based on the brand's vision, on which the mantra is based, which, in turn, initializes the positioning of the brand.

In the value pillar, the brand creates associations and offers values (functional, emotional, and self-expressing) through the identity of the brand. The mantra, which interacts with the vision and captures the spirit of the brand, is further connected with the identity of the brand as well as with its individual features. Elements that cannot be changed in time and are preserved create the core of the brand - its DNA (they represent the very provenance, originality, and history of the brand). The brand communicates outwardly through the interaction of these individual elements, leading to the development of the brand as a living organism. The identity of the brand should also be in interaction with the company's corporate identity. 


\subsection{The Dynamic Level}

The dynamic level is characterized by the processes (activities) that are already influenced not only by the company itself (where employees as well as the owners play a unique role) and the market, but also by the individual customers.

The marketing pillar is where the economic aspects of the brand are dealt with. Based on established marketing strategies, marketing mixes (individual tactics) that are constantly evolving $(4 \mathrm{P}-4 \mathrm{C}-4 \mathrm{E})$ are applied at this level. Its goal is not only to increase sales (e.g. profit), but also to increase the value of the brand, and increase brand awareness and brand knowledge. The more these activities are successful, the higher the knowledge and the general awareness of the brand, and therefore value for the label owner.

The emotional aspects the brand are dealt with within the framework of the value pillar. The brand communicates outwardly to customers at this level, and, at the same time, the customer gains experience with the band (brand experience) and a reason to buy the brand. In the beginning, customers' awareness of the brand is prompted, but with greater penetration (brand identification) this is gradually transformed into spontaneous brand awareness (brand loyalty) and then to immediate association (top of mind). With accumulated experience of the brand, mutual interaction with the brand is valued until the brand is accepted (brand perception). Image (brand perception) is created through the influence of the brand's identity and mission on the consumer's knowledge, this perception is understood as the associations that a customer makes of the brand. The brand's image provides the owners with feedback, which is established by market research.

In the legal pillar, the legal aspects of the brand are dealt with. During the existence of the law (unregistered label, trademark), conflicts with other legal systems can happen and the use of the label in connection with goods and services has to be proven. Within the framework of administrative proceedings (dispute proceedings, opposition proceedings), not only must the brand's market position and the fact that certain products and services are attached to a label (proper use) be proven, but the strengths of the brand's links and the level of identifying capacity (establishment) must also be proven.

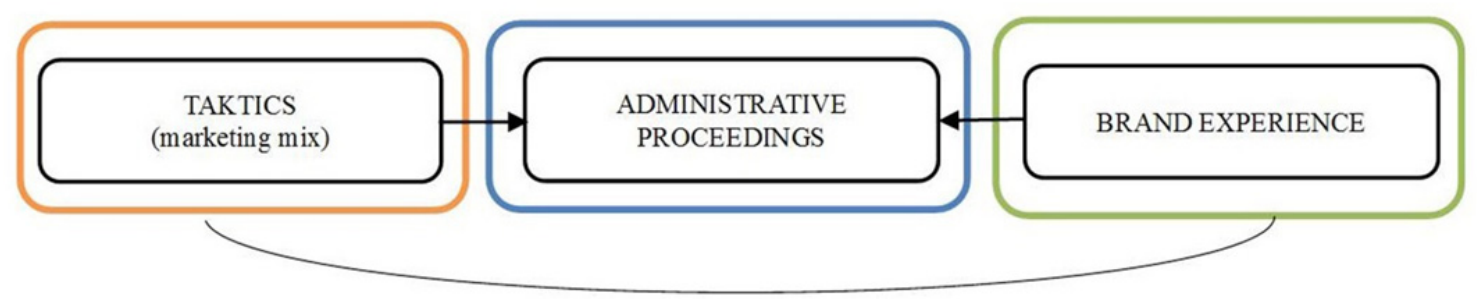

Figure 5. The Dynamic level

At the dynamic level, (Fig. 5) administrative proceedings are influenced through the tactics used and the level of the average customer's awareness, but different tactics in connection with the level of experience with the brand are also applied.

\subsection{The Top Level}

Within the framework of each pillar, large global brands strive to reach the top level, which is augmented by an established image and competent authority granted by statutes (Fig. 6) in comparison to the dynamic level.

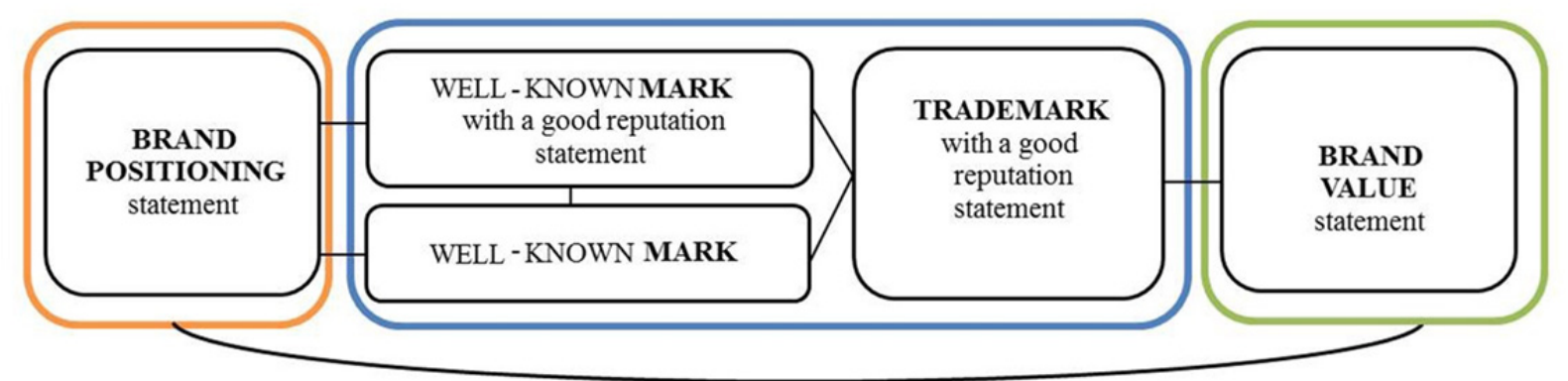

Figure 6. The Top level 


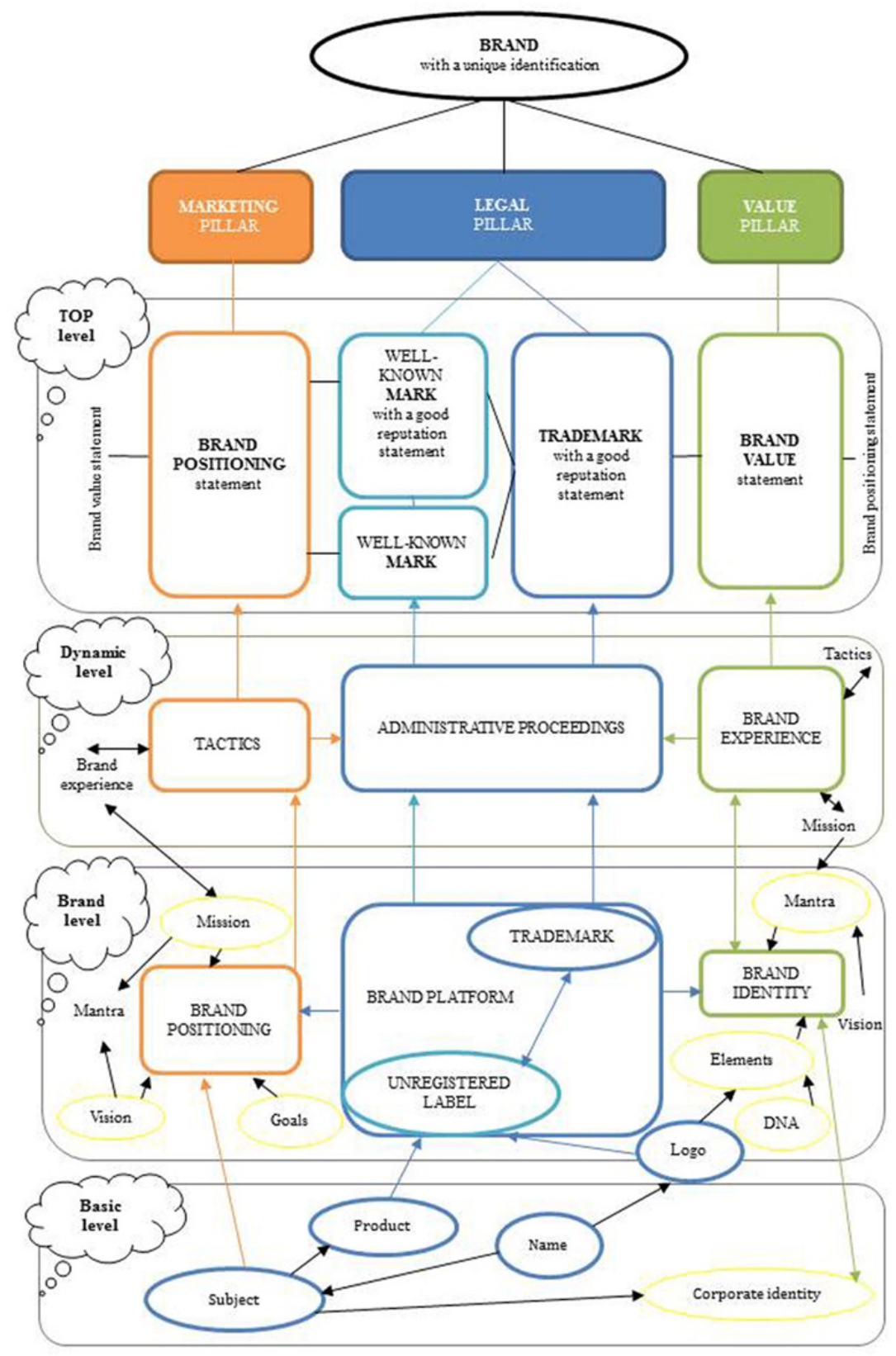

Figure 7. The theoretical model

Within the framework of the marketing pillar, the market announcement of the brand (brand positioning statement) is made, expressing the market position of the brand. It formulates several main interconnected elements into a short and clear statement defining the brand's position and its marketing power.

Within the framework of the legal pillar, an unregistered label may be declared a well-known mark during administrative proceedings. A label can become a well-known mark not as a result of the registration process, but due to its usage. Furthermore, after gaining a reputation, i.e. characteristics attributed to it by the customers themselves, a label may be declared a well-known mark with a good reputation in the case of an unregistered label, or a trademark with good reputation in the case of a registered trademark. Broader intellectual property laws are applied to these types of labels, therefore it is necessary to prove each individual attribute separately during each administrative proceedings.

In the value pillar, there is an effort to announce the highest possible value of the brand, because this value contains 
competitiveness and stability. Value means its highest economic contribution (supported for example by purpose brands) and its value (brand valuation), or the highest position in TOP charts of the best and well-known brands (brand equity), from becoming a "love" brand to passion for the brand ("brand passion"), which means gaining (quantifying) the highest possible financial or emotional value.

Theoretical model and the interconnection between its parts is shown in the scheme of Fig. 7.

\section{Conclusion}

The submitted paper looks at the concept of branding from a broader interdisciplinary perspective as a scholarly discipline on the border between management, marketing, finance, psychology, and law and emphasizes the significance of a brand's intellectual property rights. This perspective on the issue played a pivotal role in the construction of the system of its structure, the individual components and layers on which the brand itself is built upon, into a dynamic model connecting individual areas and defining the mutual relationships that influence the further expansion of the brand.

The right marketing tactics and strategies that lead to increased customer awareness, i.e. their experience, influence the brand with a unique identification, a brand with a big "B." But legal circumstances, followed by the appropriate proving of certain characteristics and their future sustainability, also influence it, because the issue of how to properly direct a brand as a trademark also works as a significant strategy of brand management, which considerably helps to strength the brand on the market and gain a competitive advantage by taking the right steps.

The owners of the brand are striving to create the most solid links to the brand, inherently strong in itself, and thus achieve and increase its stable position on the market, marketing, and legal power (brand positioning statement, well-known mark or trademark with a good reputation) not only through awareness and feedback, but also by projecting this effort onto the overall value of the brand (brand valuation, brand equity, brand love, brand passion...) by increasing it.

\section{References}

Aaker, D. A. (2003). Brand building. Brno: Computer Press.

Adamson, A. P. (2011). Jednoducho značka Brand Simple: Ako najlepšie značky stavili na jednoduchost’ a uspeli. Bratislava: Eastone Books.

Albert, N., \& Merunka, D. (2013). The role of brand love in consumer-brand relationships. Journal of Consumer Marketing, 30(3), 258-266. http://dx.doi.org/10.1108/07363761311328928.

Baines, P., Fill, Ch., \& Page, K. (2011). Marketing. Second edition. Oxford Univerzity Press.

Banerjee, S. (2008). Strategic Brand-Culture Fit: A Conceptual Frame Work for Brand Management. The Journal of Brand Management, 15(5), 312-321. http://dx.doi.org/10.1057/Palgrave.bm.2007.10

Čada, K. (2014). Strategie průmyslového vlastnictví. Praha: Metropolitan University Prague Press.

Cook T. (2013). European Union trademark law and its proposed revision. Journal of Intellectual Property Rights, 18(3), 283-286.

Cook, T. (2014). The new European commission and its work plan for EU intellectual property. Journal of Intellectual Property Rights, 19 (5), pp. 353-357.

Elaine, W., Isable, B., \& Leslie D. (2014). Consumer engagement with self-expressive brands: brand love and WOM outcomes. The Journal of Product and Brand Management, 23(1), 33-42. http://dx.doi.org/10.1108/JPBM-06-2013-0326

Herstain, R., \& Zvilling, M. (2011). Brand management perspectives in the twenty-first century. Qualitative Market Research: An International Journal, 14(2), 188-206. http://dx.doi.org/10.1108/13522751111120693

Horáček, R., Čada, K., \& Hajn, P. (2011). Práva k průmyslovému vlastnictví. Praha: C.H. Beck.

Hur, M., Ahn, K., \& Kim, M. (2011). Building brand loyalty through managing brand community commitment. Management Decision, 49(7), 1194-1213. http://dx.doi.org/10.1108/00251741111151217

Ingenhoff, D., \& Fuhrer, T. (2010). Positioning and differentiation by using brand personality attributes: do mission and vision statements contribute to building a unique corporate identity? Corporate Communications: An International Journal, 15(1), 83-101. http://dx.doi.org/10.1108/13563281011016859

Jakl, L., et. al. (2015). Vývoj v oblasti ochranných známek a designu Společenství. Praha: Metropolitan University Prague Press. 
Jakubíková, D. (2013). Strategický marketing: strategie a trendy. Praha: Grada Publishing.

Kapferer, J. N. (2008). The New Strategic Brand Management. London: Kogan Page Limited.

Keller, K. L. (1993). Conceptualizing, measuring and managing customer-based brand equity. Journal of Marketing, 57(1), 1-22. http://dx.doi.org/10.2307/1252054

Keller, K. L. (2013). Strategic Brand Management: Building, Measuring, and Managing Brand Equity. Harlow, England: Pearson Education.

Keller, K. L., \& Lehmann, D. R. (2006). Brands and branding: Research findings and future priorities. Marketing Science, 25(6), 740-759. http://dx.doi.org/10.1287/mksc.1050.0153

Kim, K., Park, J., \& Kim, J. (2014). Consumer-brand relationship quality: When and how it helps brand extensions. Journal of Business Research, 67(4), 591-597. http://dx.doi.org/10.1108/13632540610646355

Kotler, P., \& Armstrong, G. (2013). Principles of Marketing (15th ed.). Upper Saddle River, NJ: Prentice Hall.

Kotler, P., \& Keller, K. L. (2013). Marketing management. Praha: Grada Publishing

Machek, M. (2013). Architektura značek jako východisko pro strategický brand management. Ekonomika a management. Retrieved from http://www.vse.cz/polek/download.php?jnl=eam\&pdf=190.pdf

Machková, H. (2015). Mezinárodní marketing: Strategické trendy a př́klady z praxe. Praha: Grada Publishing.

Olins, W. (2016). Brand new: nová podoba značek. Praha: Slovart.

Tsai, S. P. (2011). Strategic relationship management and service brand marketing. European Journal of Marketing, 45(7/8), 1194-1213. http://dx.doi.org/10.1108/03090561111137679

Vysekalová, J. et al. (2014). Emoce v marketingu: jak oslovit srdce zákaznika. Praha: Grada Publishing.

\section{Copyrights}

Copyright for this article is retained by the author(s), with first publication rights granted to the journal.

This is an open-access article distributed under the terms and conditions of the Creative Commons Attribution license (http://creativecommons.org/licenses/by/3.0/). 